\title{
Verification of Vehicular Emitted Aerosol Components in Soil Biochemical Characteristics in Owerri West Local Government Area, Imo State, Nigeria.
}

\author{
Dr. Ubuoh Emmanuel Attah \\ Department of Urban and Regional Planning, \\ Federal University of Technology, Owerri, Imo State, Nigeria.
}

\begin{abstract}
The study was carried out in Avu Junction in Owerri West L.G.A. at graded distant from the tarred road with an average vehicular flow between 10,000 to 12,000 per day. Soil samples were taken at the distant of $50 \mathrm{~m}, 100 \mathrm{~m}, 150 \mathrm{~m}$ and $200 \mathrm{~m}$ respectively. And auger soil samples were taken at the depths of $0-30 \mathrm{~cm}$ and $30-45 \mathrm{~cm}$ accordingly. Soil factor, heavy metals and microbial populations were investigated at graded distances. From the result of soil factors, $p H$ values indicated acidity with decreased distant from the tarred road ranging between 4.52 6.32, soil temperature on the topsoil was higher than subsoil ranging between $19-25^{\circ} \mathrm{C}$ and 18 $-22{ }^{\circ} \mathrm{C}$ and soil moisture increases with increased distant from the tarred road ranging between $10.00-13.3$. Heavy metal concentrations in the soil increased with decreased distant in the order of $\mathrm{Pb}<\mathrm{Zn}<\mathrm{Ni}<\mathrm{Cu}<\mathrm{Cd}$. Overall results revealed that $\mathrm{Cd}$ in the soil constitutes the highest percentage of $91.7 \%, \mathrm{Ni} 90.9 \%, \mathrm{Cu} 90.1 \%, \mathrm{~Pb} .84 .7 \%$ and $\mathrm{Zn} .81 .7 \%$. Significantly, higher fungi and bacterial populations were recorded at increased distant from the tarred road. This then called for proactive measures to checkmate soil contamination due to pollutants from vehicular flows.
\end{abstract}

Keywords: Aerosol, Biochemical, Vehicular, Soil Factors and Heavy Metals.

\section{INTRODUCTION}

Roads form the main system of transportation of the region. Driving a car is the most air polluting act an average citizens commits. Roadside soils often show a high degree of contamination that can be attributed to motor vehicles (Weckwerth ,2001). This is because car exhaust is toxic at ground level. Trace heavy metal contamination in the soils is a major concern because of their toxicity and the threat to human life and environment (Barbhuiya et al, 2008) .This has led to the loss of forest cover and subsequent loss of soil fertility. Heavy metals such as $\mathrm{Cu}, \mathrm{Cd}, \mathrm{Ni}$, and $\mathrm{Pb}$ are potential soil and water pollutants ( Mander, 1983; Pagotto et al (2001). Vehicular discharge of numerous gaseous and trace metals contaminants due to incomplete combustion of petroleum fuel adversely affects the microbial population and their activities in soil. Contamination of litter and soil with metals can result in reduced rates of litter decomposition, soil respiration, nitrogen mineralization and soil enzyme activity (Tyler et al, 1989). Moderate soil contamination by metals has been shown to reduce the soil microbial biomass and certain indices of its activity (Brooks et al, 1986).

The interactions of chemical, physical and biochemical factors are responsible for holding the complex soil system in a dynamic equilibrium. Population dynamics of soil microorganisms is largely regulated by vegetation and soil 
characteristics. Soil micro flora exerts considerable influence on soil fertility and plant growth. Biochemical processes provide better estimates of the functional attributes of the microorganisms in an ecosystem. These are generally determined by the estimation of the rate of biochemical processes involving microbial enzymes, and soil factors. Enzymes in soil are biologically significant as they are involved in cycling of nutrients and can influence the availability of nutrients to plants thus playing an important role in the initial phase of decomposition of organic matter (Joshi, 1991).Tropical and sub-tropical soils have received less attention in relation to microbial dynamics as affected by disturbances (Joshi et al, 1992; Barbhuiya et al, 2008).

The present study aims to understand the influence of roadside pollution caused by vehicular flow/density on population and activity of microorganisms and physicochemical properties of the soil in Owerri West Local Government Area of Imo State.

\section{MATERIALS AND METHODS}

\section{(a) Study Area}

The research study is carried out in Owerri West Local Government Area of Imo State. It is located in the southern part of the State within latitude $06^{\circ} 52^{\prime} \mathrm{E}$ and $07^{\circ} 05^{\prime} \mathrm{E}$, longitude $05^{\circ}$, $15^{\prime} \mathrm{N}$ and $05^{\circ} 34^{\prime} \mathrm{N}$ of the South East Zone of Nigeria. It comprises about 16 autonomous communities and share common boundary with villages like Ohaji/Egbema, Mbaitoli, and the area has a total landmass of about 3,787 square $\mathrm{km}$. The area is sandy-loamy and some sandyclay loam that has made the zone good for agriculture. It has mean annual rainfall of about 2250 $-3000 \mathrm{~mm}$ that begin from the months of March to October, and the temperature ranges from $35^{\circ} \mathrm{C}-37^{0} \mathrm{C}$. It is situated within tropical rainforest that has evergreen broad leaves. Traffic flow in this area is very slow coupled with the police check point that retarded the flow and vehicles spent $30-45$ minutes with their engines steaming.

\section{(b) Soil Samples Collection Techniques:}

The study site considered for the present study was Avu- Port Harcourt Roads with heavy vehicular flow where soil samples were collected at graded distances of $50 \mathrm{~m}, 100 \mathrm{~m}$, $150 \mathrm{~m}$ and $200 \mathrm{~m}$ away from the road side, and two soil samples were collected from each points at the depths of 0.30 and $30-40 \mathrm{~m}$ respectively. Samples collected were analyzed for the following:

(1) Soil Factors such as soil $\mathrm{pH}$, soil temperature and soil moisture

(2) Heavy Metals such as Lead (Pb), Cadmium (cd), Copper (cu), Zinc (zn), and Nickel (Ni) and ,

(3) Microbial Population to include fungal, and bacterial

\section{(c) Laboratory Analytical Techniques:}

For analyses in the laboratory, soil factor such as soil $\mathrm{pH}$, soil temperature (ST), and soil moisture content (SMC), and bacterial counts (BC) were also observed.pH of sampled soils were determined from supernatant obtained after 1:1 (w:v ) mixture of the soil samples were made with sterile distilled de-ionized water. The $\mathrm{pH}$ was further measured using a PYE 
UNICAM model $291 \mathrm{mkz} \mathrm{pH}$ meter with a combined glass electrode. The temperature of each soil sampled was measured using Mercury-in-glass thermometer that was inserted into the affected soil for $20-30 \mathrm{~cm}$ beneath the soil for 5 minutes to stabilize for accurate reading , and was done onsite.

For the determination of soil moisture content of each soil sampled, APHA (1985) was used for the measurement. 10 grams of each soil sample was heated in a hot air for $8-12$ hours at $80^{\circ} \mathrm{C}$ till constant weight was obtained. The difference between the original weight and the consistent final weight obtained was taken as the weight of the moisture content of the soil samples. Fungal populations were estimated by Warcup's soil plate method using rose bengal agar medium. The inoculated plates were incubated at $25 \pm 1^{\circ} \mathrm{C}$ and colony forming units were enumerated after 5 days. Dilution plate method was used to estimate bacterial populations developing on nutrient agar medium. The inoculated plates were incubated at $30 \pm 1^{\circ} \mathrm{C}$ and colony forming units were enumerated after $24 \mathrm{~h}$ from the plate of higher dilutions (Prescot et al, 1988).

\section{RESULTS AND DISCUSSION}

The results of the study are presented in Table 1- Table 4

TABLE 1 : Variations of Soil Factors at the Graded Distance

\begin{tabular}{|c|c|c|c|c|c|}
\hline S/N & $\begin{array}{c}\text { Sample } \\
\text { Points }\end{array}$ & $\begin{array}{c}\text { Depth } \\
(\mathbf{c m})\end{array}$ & $\mathbf{p H}$ & $\begin{array}{c}\text { Soil Temperature } \\
(\mathbf{0} \mathbf{C})\end{array}$ & Soil Moisture \\
\hline \multirow{2}{*}{1} & \multirow{2}{*}{2} & $0-30$ & 4.52 & 25 & 10.1 \\
\cline { 3 - 6 } & & $30-40$ & 5.10 & 21 & 10.00 \\
\hline \multirow{2}{*}{3} & \multirow{2}{*}{3} & $0-30$ & 5.15 & 23 & 10.1 \\
\cline { 3 - 6 } & \multirow{2}{*}{40} & $30-40$ & 5.17 & 21 & 10.01 \\
\cline { 3 - 6 } & & $0-30$ & 5.75 & 19 & 10.6 \\
\hline \multirow{2}{*}{4} & 200 & $0-40$ & 5.96 & 18 & 11.1 \\
\cline { 2 - 6 } & & $30-40$ & 6.25 & 24 & 13.3 \\
\hline
\end{tabular}

\section{Source: Fieldwork, 2010}

From Table 1, the result shows that soil factors such as $\mathrm{pH}$, soil temperature and soil moisture varied considerably. At the distant of $50 \mathrm{~m}$ with the depth of the soil within $0-45 \mathrm{~cm}$ soil $\mathrm{pH}$ varied between $4.52-5.10$, soil temperature $21-25^{\circ} \mathrm{C}$, and $10-10.1 \%$. At $100 \mathrm{~cm}$, soil $\mathrm{pH}$ at the same depth ranged between $5.15-5.17$, soil temperature $21-23^{\circ} \mathrm{C}$, and soil moisture $10.01-10.1 \%$. At $150 \mathrm{~cm}$ and $200 \mathrm{~cm}$, soil $\mathrm{Ph}$ ranged between $5.75-5.96$, soil temperature $18-$ $19{ }^{\circ} \mathrm{C}$, Soil moisture $10.6-11.1 \%$ and soil $\mathrm{pH}$ ranged between $6.25-6.32$, soil temperature $22-$ $24^{\circ} \mathrm{C}$, and soil moisture ranged between $13.1-13.3 \%$ respectively. The results further indicated that soil $\mathrm{pH}$ from the main road is more acidic than soil sampled away from the main road that moves toward alkalinity, and the top soil at the depth of $0-30 \mathrm{~cm}$ was also more acidic than soil depth of $30-45 \mathrm{~cm}$ ( Fig.1). At the same depths, the top soil had an increased in temperature than the sub-soil and the surface temperature decreases with distant. The same trend is found in soil moisture which is influenced by heat intensity from ambient temperature. 


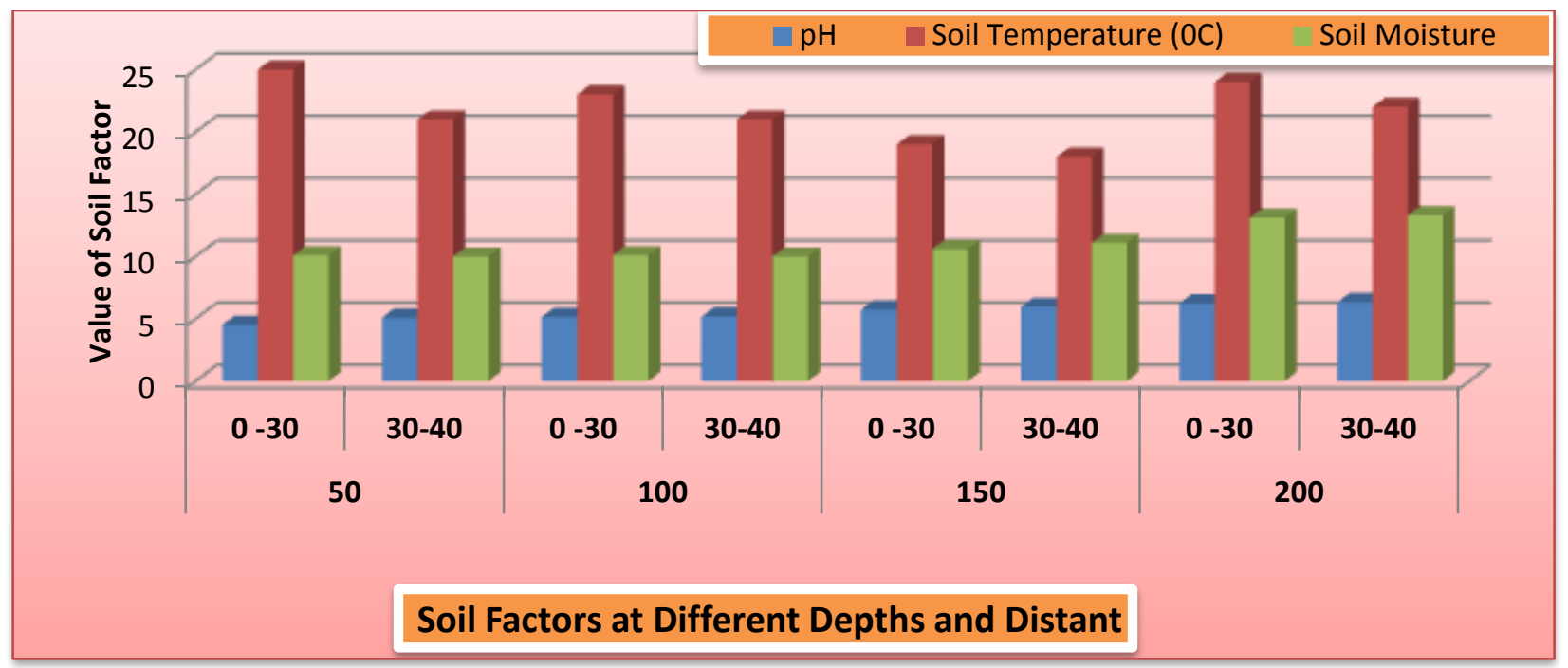

Fig.1: Variation of Soil Factors at different Depths and Distant

Table 2 :Heavy Metal Concentrations in the Soil at Graded Distance

\begin{tabular}{|c|c|c|c|c|c|c|c|}
\hline $\mathbf{S} / \mathbf{N}$ & $\begin{array}{c}\text { SAMPLE POINT } \\
(\mathrm{m})\end{array}$ & Depth $(\mathrm{Cm})$ & $\begin{array}{c}\mathbf{P b} \\
(\mathbf{K g})\end{array}$ & $\begin{array}{c}\mathbf{C d}(\mathrm{K} \\
\mathrm{g})\end{array}$ & $\mathrm{Cu}(\mathrm{Kg})$ & $\begin{array}{c}\mathbf{Z n} \\
(\mathbf{K g})\end{array}$ & $\begin{array}{c}\mathrm{Ni}(\mathrm{K} \\
\mathrm{g})\end{array}$ \\
\hline \multirow[t]{2}{*}{1} & \multirow[t]{2}{*}{50} & $0-30$ & 4.95 & 1.65 & 1.74 & 4.78 & 2.51 \\
\hline & & $30-45$ & 1.95 & 1.15 & 1.72 & 2.40 & 1.75 \\
\hline \multirow[t]{2}{*}{2} & \multirow[t]{2}{*}{100} & $0-30$ & 2.40 & 0.85 & 1.01 & 3.43 & 1.95 \\
\hline & & $30-45$ & 0.91 & 0.95 & 1.65 & 1.51 & 1.31 \\
\hline \multirow[t]{2}{*}{3} & \multirow[t]{2}{*}{150} & $0-30$ & 1.90 & 1.15 & 0.94 & 1.51 & 0.41 \\
\hline & & $30-45$ & 0.85 & 0.78 & 0.94 & 1.48 & 0.56 \\
\hline \multirow[t]{2}{*}{4} & \multirow[t]{2}{*}{200} & $0-30$ & 1.90 & 0.62 & 0.48 & 1.51 & 0.52 \\
\hline & & $30-45$ & 0.65 & 0.62 & 0.86 & 1.62 & 0.55 \\
\hline \multirow{2}{*}{\multicolumn{3}{|c|}{$\begin{array}{l}\text { Total } \\
\text { Mean }\end{array}$}} & 15.51 & 7.74 & 9.34 & 18.24 & 9.10 \\
\hline & & & 1.94 & 0.94 & 1.17 & 2.28 & 1.14 \\
\hline \multirow{2}{*}{\multicolumn{3}{|c|}{$\begin{array}{l}\text { STD } \\
\text { Coefficient }\end{array}$}} & 10.16 & 11.0 & 10.8 & 9.78 & 10.9 \\
\hline & & & $84.7 \%$ & $91.7 \%$ & $90.1 \%$ & $81.6 \%$ & 90.9 \\
\hline
\end{tabular}

Source: Fieldwork, 2010

From Table 2, the results shown that heavy metal concentrations in the soil at graded distances varied from one point to the other. For instant at $50-200 \mathrm{~m}$ with the soil depth of 30 $\mathrm{cm}$, lead ranged between $1.90-4.95 \mathrm{~kg}, \quad 30-450.65-1.95 \mathrm{~kg}$, cadmium $0.62-1.65 \mathrm{~kg}$ and $0.62-1.15 \mathrm{~kg}$, copper $0.48-1.74 \mathrm{~kg}$ and $0.86-1.72 \mathrm{~kg}$, zinc $1.51-478 \mathrm{~kg}$ and $1.62-2.40 \mathrm{~kg}$, nickel $0.41-2.51 \mathrm{~kg}$ and $0.55-1.75 \mathrm{~kg}$ respectively. Above all, lead concentration in the soil was found to have a total of 1551 with mean of 1.94, standard deviation of 10.16 with coefficient of $84.7 \%$. Cadmium had a total of 7.74 with mean of 0.94 , standard deviation of 11.0 with coefficient of $91.7 \%$ and cadmium comes mostly from diesel fuel (Dierkes and Geiger, 1999) . Copper had a total of $9.34 \mathrm{~kg}$ with mean of 1.17 , standard deviation of 10.8 with coefficient of $90.1 \%$. Zinc had a total $18.24 \mathrm{~kg}$ with mean of 2.28 , standard deviation of 9.78 with 
coefficient of $81.6 \%$ and zinc concentration in the roadside has been confirmed to be tires wear of vehicles Krzysztofiak (1984) and nickel had a total concentration of $9.10 \mathrm{~kg}$ with mean of 1.14, standard deviation of 10.9 and coefficient of $90.9 \%$ respectively. And according to Parry et al (1981), Joshi et al (1991), metals concentrations in the roadsides like lead is caused by leaded gasoline, tire wear, lubricating oil, grease and bearing; zinc is caused by tire wear, motor oil, engine parts, brake emission; copper, cadmium and nickel are caused by bearing wears, fuel burning, batteries and lubricating oil.

From the results, it is further observed that heavy metal concentrations were higher in the top soils at the depths of $0-30 \mathrm{~cm}$ and the concentrations decreased with distance from the road side ( Fig.2). And these then indicated soil being polluted by heavy vehicular flows. The results is further explained by authors like Ihenyen (1992), Weckwerth (2001), who attributed high degree of heavy metal contamination in the soil due to motor vehicles. Dierkes and Geiger (1999) viewed that among the larger number of heavy metals, lead ,cadmium and zinc are the most common metals that accumulates in the roadsides soils. But, the overall results indicated that cadmium had the highest percentage of concentration in the soil followed by nickel and third copper.

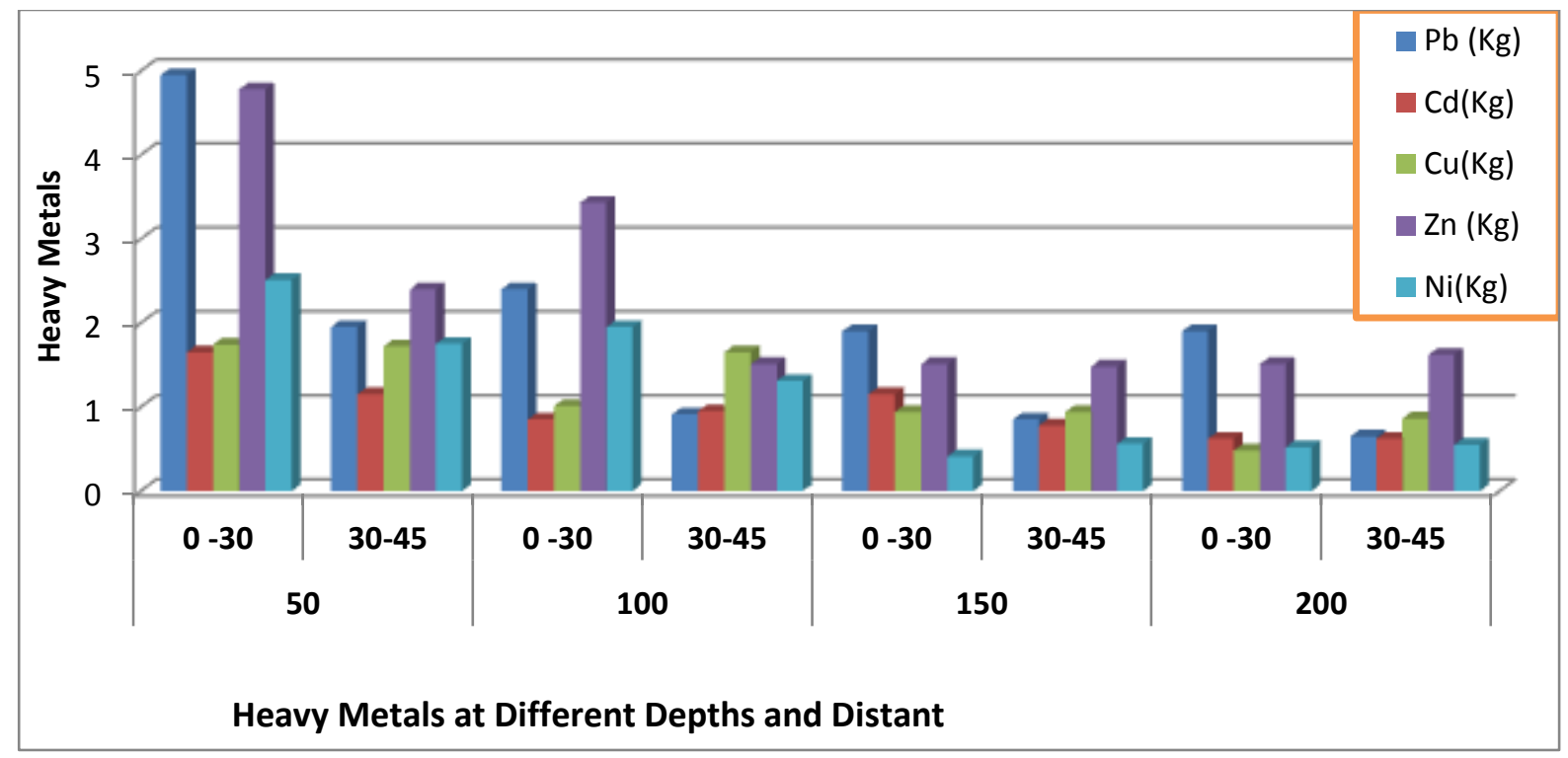

Fig.2: Variation of Heavy Metal Concentrations in the Soil at Graded Distance

Table.3: Soil Bacterial at Graded Distant

\begin{tabular}{|l|l|l|l|l|l|l|}
\hline \multirow{2}{*}{ SOIL BACTERIAL } & Unit & $\mathbf{5 0 m}$ & $\mathbf{1 0 0 m}$ & $\mathbf{1 5 0 m}$ & $\mathbf{2 0 0 m}$ \\
\cline { 4 - 7 } & & $\mathbf{0 - 3 0 c m}$ & $\mathbf{0 - 3 0 c m}$ & $\mathbf{0 - 3 0 c m}$ & $\mathbf{0 - 3 0 c m}$ \\
\hline 1 & Thermophillus Bacilli(TB) & $\mathrm{Cfu} / \mathrm{g}$ & $1.9 \times 10^{3}$ & $1.6 \times 10^{7}$ & $1.5 \times 10^{3}$ & $1.3 \times 10^{4}$ \\
\hline 2 & Streptococcus Cremoris & $\mathrm{Cfu} / \mathrm{g}$ & $1.4 \times 10^{7}$ & - & - & - \\
\hline 3 & Streptococcus Spp & $\mathrm{Cfu} / \mathrm{g}$ & $1.6 \times 10^{5}$ & - & - & - \\
\hline 4 & Streptococcus Cremoris & $\mathrm{Cfu} / \mathrm{g}$ & $1.4 \times 10^{3}$ & - & $1.4 \times 10^{2}$ & $1.3 \times 10^{1}$ \\
\hline
\end{tabular}




\begin{tabular}{|l|l|l|l|l|l|l|}
\hline 5 & Bacillus Spp & $\mathrm{Cfu} / \mathrm{g}$ & $1.3 \times 10^{7}$ & - & - & - \\
\hline 6 & Nitrosococuss nitrosus & $\mathrm{Cfu} / \mathrm{g}$ & - & $8 \times 10^{4}$ & - & - \\
\hline 7 & Clos tridilum Spp & $\mathrm{Cfu} / \mathrm{g}$ & - & $1.2 \times 10^{3}$ & - & - \\
\hline 8 & Microecus Varians & $\mathrm{Cfu} / \mathrm{g}$ & - & $1.2 \times 10^{3}$ & - & - \\
\hline 9 & Pseudomonas Spp & $\mathrm{Cfu} / \mathrm{g}$ & - & $1.0 \times 10$ & $1.4 \times 102$ & $1.5 \times 10^{3}$ \\
\hline 10 & Spirillium Spp & $\mathrm{Cfu} / \mathrm{g}$ & - & $1.5 \times 10$ & $12.2 \times 10^{6}$ & $13 \times 10^{4}$ \\
\hline 11 & Agrobacter Spp & $\mathrm{Cfu} / \mathrm{g}$ & - & - & $1.6 \times 10^{6}$ & $1.9 \times 10^{6}$ \\
\hline 12 & Bacillius Thermoplilus & $\mathrm{Cfu} / \mathrm{g}$ & - & - & $1.7 \times 10^{6}$ & $11 \times 10^{5}$ \\
\hline 13 & Nitrosomonas eunpae & $\mathrm{Cfu} / \mathrm{g}$ & - & - & - & - \\
\hline
\end{tabular}

Source: Fieldwork, 2010

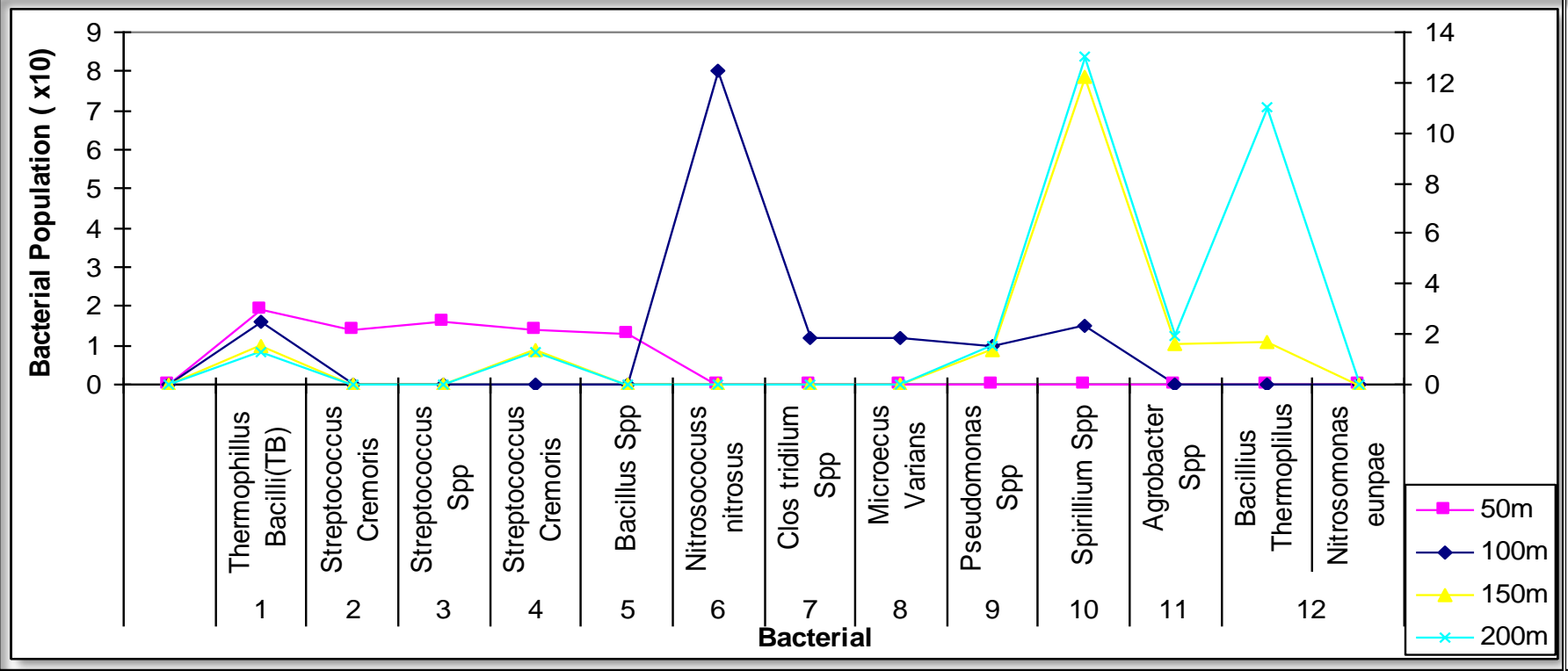

Fig.3: Variations of Bacterial Population in the Soil with Distance from the Roadside

Table 3 refers to the bacterial population in the soil at the graded distant away from the roadside.

From the results, some bacterial populations showed an increasing trend with decreasing distant from the roadside while some showed increasing trend with increasing distant away from the roadside. For instant, thermophillus Bacilli bacterial population that can survive under an increased temperature Pagotto et al (2001), indicating that at 50m with the soil depth of $0-30$ $\mathrm{cm}$, the TB was more in population, while at $200 \mathrm{~m}$ with the soil depth of $0-30 \mathrm{~cm}$ the TB was less (Fig.3). This trend was experienced in bacterial population like Streptococcus Cremoris which is equally attributed to high temperature from the roadside, and it could also survive at the 
lower temperature with the present of organic matter or availability of organic substrates in the soil away from the roadside (Mishra, 2001).Conversely Streptococcus Cremoris_and, Bacillus $\underline{S p p}$ could not survive lower temperature inversion in the soil this then lead to complete extinction. Above all, others could not survive the increased in temperature closed to the roadside, but survived away with increased population. Genera like Nitrosomonas eunpae was completely not available in the soil attributed to it susceptibility to environmental factors. The results of this kind is in line with the report of air pollution on soil microbe by Brookes et al (1986), who observed 41.6 percent reduction in soil species quantity, 37.5 percent in species density, 69.5 percent reduction in dominance of oribatida due to air rich in heavy metals. Williamson and Evans (1973), Post et al (1996) observed a decrease in abundance of mites due to the high level of inorganic lead in the soil with the increasing distance from the source of emission. The reduction of microbial activity in the roadside soil due to vehicular pollution has been confirmed by authors Brookes et al (1986) .Reduction of bacterial and fungal community showed a significant decline from main road, and the reduction was suggested to be the result of heavy metal concentrations in the soil at distant that ranged between $50-200 \mathrm{~m}$. The result is consistent with the finding of (Joshi et al, 1991).

Table 4: Soil Fungi Isolated at Graded Distance

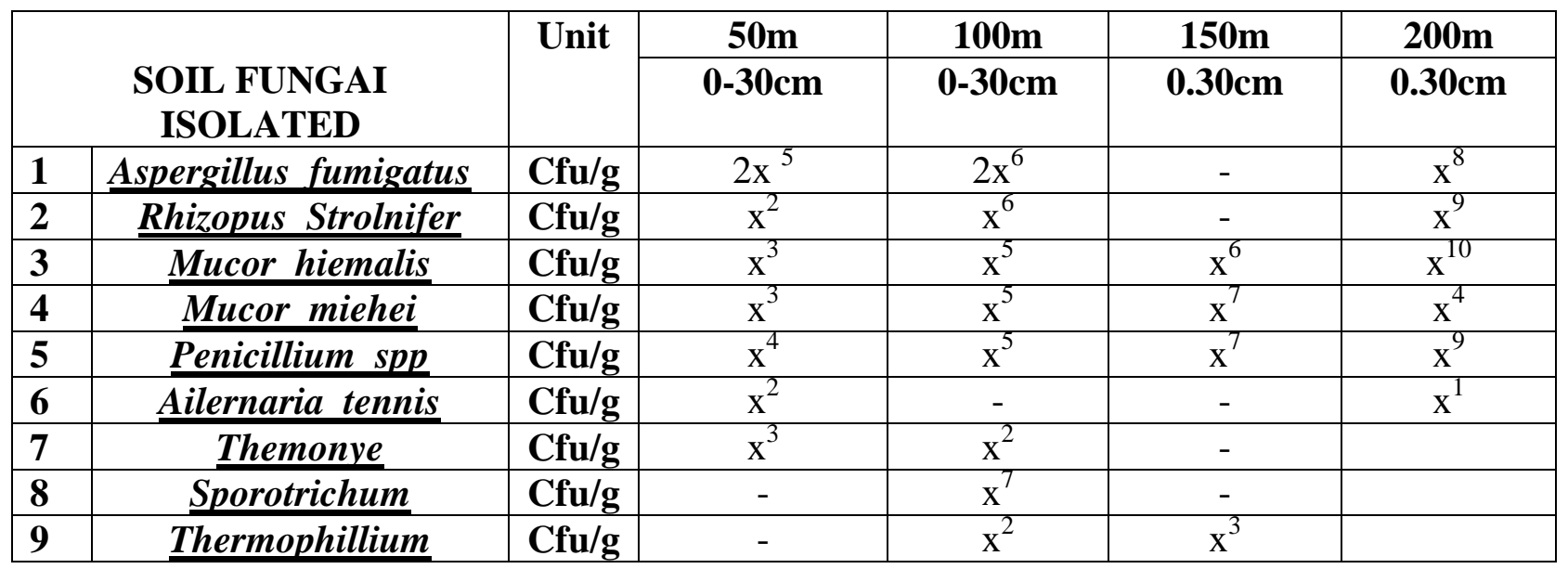




\begin{tabular}{|c|c|c|c|c|c|c|}
\hline 10 & Asperallusniger & $\mathrm{Cfu} / \mathrm{g}$ & - & - & $x^{4}$ & - \\
\hline 11 & $\overline{\text { Hernicola grisea }}$ & Cfu/g & - & - & $x^{5}$ & $x^{6}$ \\
\hline 12 & Emericella indulcna & $\mathrm{Cfu} / \mathrm{g}$ & - & - & $x^{8}$ & $x^{12}$ \\
\hline 13 & Fursarium Spp & $\mathrm{Cfu} / \mathrm{g}$ & - & - & $x^{2}$ & $\mathrm{x}^{3}$ \\
\hline 14 & Aspergillus Flerns & $\mathrm{Cfu} / \mathrm{g}$ & - & - & $x^{4}$ & \\
\hline 15 & Alternaira spp & Cfu/g & - & - & - & \\
\hline 16 & $\overline{\text { Ascomyces spp }}$ & $\mathrm{Cfu} / \mathrm{g}$ & - & - & - & \\
\hline
\end{tabular}

Source: Fieldwork, 2010.

From Table 4, fungi population densities are higher in 200m, 150 and 100m away from the roadside, while there is decrease in fungi population at $50 \mathrm{~m}$ along the roadside. The decrease in number of soil microbes can be attributed to the effects of vehicular flows that emits heavy metals and the wearing of tire along the road side. The result is consistent with the finding of (Acea and Carballa, 1985; Nwaugo et al, 2005).The results also indicated that greater number of microbes such Aspergillus fumigatus, Rhizopus Strolnifer, Mucor hiemalis, Mucor miehei, Penicillium spp, Ailernaria tenniss, and Themonye were isolated at 50m (Brookes, et al, 1986; Chessbrough, 1987) stated that good spore formers can survive within harsh environmental conditions like in the $50 \mathrm{~m}$ soil samples.

\section{SUMMARY AND CONCLUSION}

From the results, it is observed that soil $\mathrm{pH}$ was lower at $50 \mathrm{~m}$ from the roadside indicating acidity in the soil which affect productivity of the soil the reflected the stunted plant growth near the roadside. Soil temperature was also identified along the roadside with decreased soil moisture at decreased distant. Also heavy metals were found closed to the main road. Similarly greater number of bacteria and fungal were found in greater population at distance away from the soil samples closed to the roadside. This has affected the activities of microorganisms the would have helped in decomposition process for mineralization and mobilization of soil nutrients. It is then concluded that since there is little or no human activity along the roadside, heavy traffic has caused the declined in the microbial population in the study area.

It is the recommended that, for sustainable soil quality management for food production:

(1) Affected soil with low pH should be limed

(2) Ring - roads should be constructed to divert traffic in Owerri west

(3) Maintenance of vehicles should be monitored by vehicles inspection officers (VIO) to make sure that vehicles are not smoked unnecessarily.

(4) Exotic trees should be planted linearly for gaseous exchange for air quality

(5) The soil that is heavily contaminated with lead should not be used for growing of food crops but for ornamentals trees.

(6) Farmers working on the contaminated soil should wear gloves and shoes to avoid self contamination

(7) And farmers should remove gloves and shoes at the doorway to avoid tracking soils indoors where children play on the floor. 


\section{REFERENCES}

[1] Acea, M. J. and T. Carballa, (1985): First Results of Study of the Microbial Population of humid zone gr. Agrobiologia, 44: 395 - 412.

[2] APHA, (1985): Standard Methods for the Examination of Wastewater, $15^{\text {th }}$ Edition. American Public Health Association. Washington, D.C.

[3] Barbhuiya, A. R., A. Arunachalam, P.C. Nath, M.L., Khan and K. Arunachalam, (2008): Leaf litter decom Namdapha National Park, Arunachal Pradesh, Northeast India. J. Forest Res., 13: 23-34.

[4] Brookes, P.C., S.P. McGrath and Heijnen, (1986): "Metal Residues in Soil Previously Treated with Sulphur and Nitrogen Fixation by Blue-green algae." Soil Biol.Biochem, 19: $219-220$.

[5] Chessbrough, M. (1987): Medical Laboratory Manual for Tropical Countries $4^{\text {th }}$ Edition. Tropical Health Technology and Butterworth, London.

[6] Dierkes, C. and W. F. Geiger, (1999): "Pollution Retention Capabilities of Roadsides Soils". Water Science Technology. Pg. 201-208.

[7] Ihenyen , A.E., (1992): "Trace Metals in Bottom Sediments of Harbour of Lagos, Nigeria". Environmental Monitoring and Assessment. Pg.259-264.

[8] Joshi, S.R. G.D. Sharma and R.R. Mishra, (1993): "Microbial Enzyme Activities related to litter decomposition of the North-East India." Soil Biol. Biochem.,25:1763 1770 .

[9] Joshi, S.R., M. Chauhan, G.D. Sharma and R. R. Mishra, (1991):Effect of Deforestation on Microbes, Eastern Himalaya. In : Studies in Himalaya Ecobiology, Rajwas, G. S. (Ed.). Today and tomorrow.

[10] Krzysztofiak, L., (1984): "Contents of Copper, Zinc, and Lead in Ant. Lasius Niger (L) Occurring on Roadside Lawns". Bull. Pollution Acad. Sci. Biol. Sciences. Pg. 851854.

[11] Mander, U. (1983): The Effect of Roadside Woods and Hedges on the distribution of Heavy Metals alongside Motorways. Acta et comm., Univ. Tartuensis 647: 50- 66 (In Russian, summary in English).

[12] Mishra, P. C. (2001): Soil Pollution and Soil Organisms. Published by Ashish Publishing House, New Delhi, pg 62-85. 
[13] Nwaugo, V.O., Onyeagba, R. A. and N.C. Nwahchukwu , (2005): Effect of Gas Flaring on Soil Microbial Spectrum in parts of Niger Delta, Microbiological Department, Abia State University, Uturu, Nigeria.

[14] Pagotto, C.N. Remy, M. Legret, and P.Cloirec, (2001): "Heavy Metal Pollution of Road Dust and Roadside". Environment Techn., 22:307-319.

[15] Parry, G.R. Jonhnson, M.S. and R.M. Bell, (1981): Trace Metal Survey of Soils as a Policy Development. Environmental Pollution Service. Pg. 97-107.

[16] Post, R. D. and A.N. Beeby, (1996): "Activity of the Microbial Decomposer Community in Metal-contamination", Environment Techn Vol 4. p $703-709$.

[17] Prescot, L.M. and Harley, J.P. and D. A. Klein, (1988): Microbiology $4^{\text {th }}$ Edition, WCB, McGraw Hill New York, London.

[18] Tyler, G. ,A. M Pahlsson. ,G. Bengtsson, E. Baath and L. Tranvik, 1989. Heavy Metal Ecology of ten vertebrates. Water Air Soil Pollution, 47:189-215.

[19] Weckwerth, G.,( 2001):"Verification of Traffic Aerosol Component in the Ambient Air of Colognou"s. Pg 36-55.

[20] Williamson, P. and P.R. Evans, (1973): "A Preliminary Study of the Effects of High Levels Inorganic Lead on Soil Fauna”. Pedobiologia. Pg. 16-21. 